\title{
Elephant Memory
}

'The beholder finds an irresistible urge to search a picture for the tiny spark of contingency, of the here and now, with which reality has seared the subject, to find the inconspicuous spot where in the immediacy of that long-forgotten moment the future nests so eloquently that we, looking back, may rediscover it' (Benjamin 1979 [1997]: 243).

'Ruins embody a set of temporal and historical paradoxes. The ruined building is a remnant of, and portal into, the past; its decay is a concrete reminder of the passage of time. And yet by definition it survives, after a fashion: there must be a certain (perhaps indeterminate) amount of a built structure still standing for us to refer to it as a ruin and not merely as a heap of rubble.'

(Dillon 2011: 11).

'Very often the Punctum is a "detail," i.e., a partial object. Hence, to give examples of punctum is, in a certain fashion, to give myself up.'

(Barthes 2000: 43).

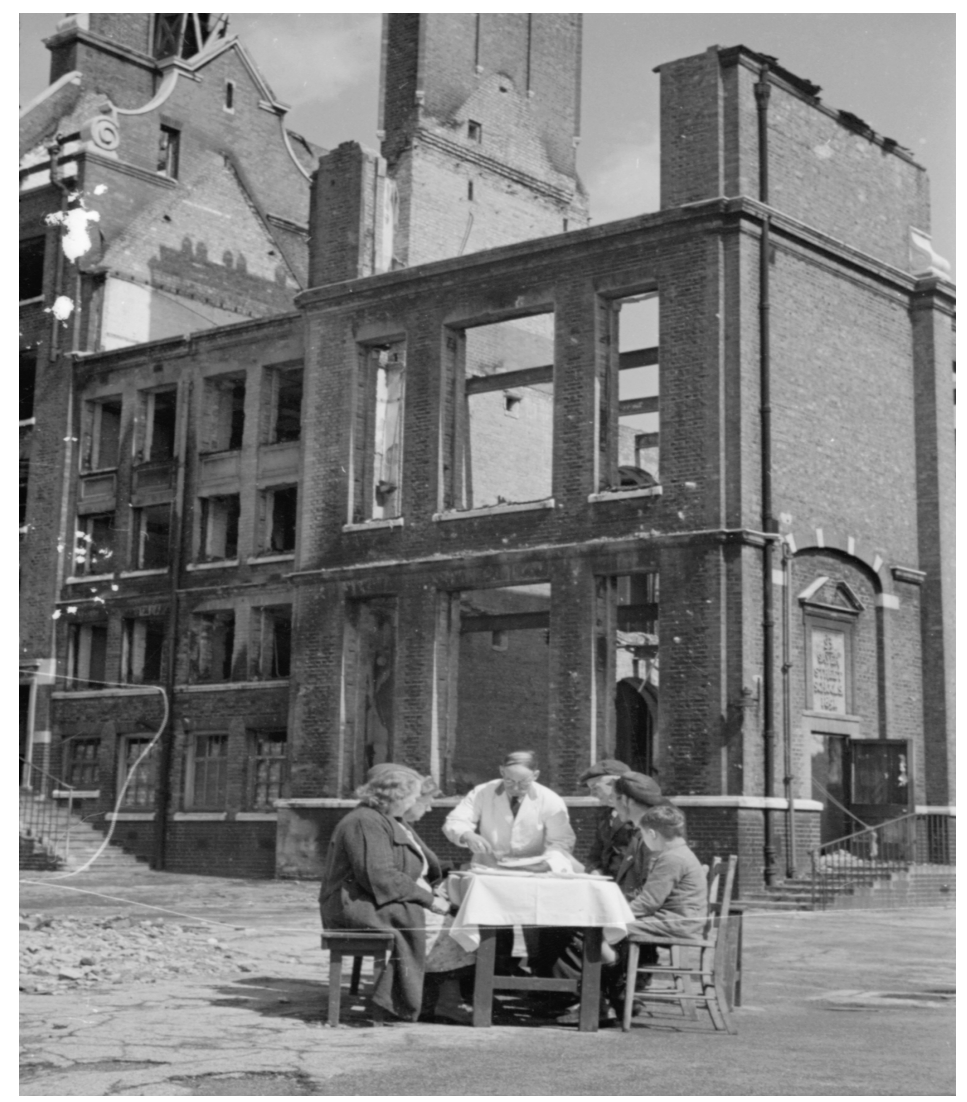

Figure 1. Sayer Street, 1941 Image (C) Imperial War Museum

The information accompanying the image above, held in the Imperial War Museum, archive is spare. We learn that it was taken some time in the late summer or early autumn of 1941. There is a group of people sitting around a table outside the ruins of a school in Sayer Street. A white-jacketed waiter is serving them bacon and eggs. 
The image and all it seems to contain becomes, in my walking and in-between walking of 'Elephant Memory' a fixation. I will return to this.

\section{A beginning}

'Elephant Memory' was the title of a walk that I first led in April 2016 at the invitation of the Royal College of Art's Fine Art Research Programme (FARP) as part of a symposium called 'The Matter of Spatial Narratives'. There have since been other reconnoitring of and around the route followed on that day and each of these has added to a layering of documentary fragments (literal 'foot notes' perhaps), in the form of image capture, note book scribbling and voice recording, made during or as soon after the walks as possible and all informing on this writing. The idea I had for my narrative came out of the coincidence of walking with a friend, Jia Qiu, a visiting Professor of Fine Art from Shanghai University who shared my preoccupation with uncovering an area's hidden and not so hidden layers, around the Elephant and Castle in south east London and specifically the emerging Elephant Park residential and retail development.

Although no field notes were made, the walk with Jia became, amongst other things, a sort of catharsis, that is, a vehicle for me to talk about my past - our conversation centred on my biographical connection to the area (as well as presently working at the London College of Communication I had originally come to the area to study at South Bank Polytechnic in the late 1970s and then later lived on the nearby Aylesbury Estate between 1980 until 1985). This latter fact provided a focal point for where the walk ended up - on the tenth-floor landing of Taplow tower block, outside the door of the flat I lived in for five years.

\section{The Punctum in the Ruin}

I prepare for the FARP walk by doing some cursory online research into the area's history. Quite soon into the process, via Peter Watts' use of it in his blog 'The Great Wen, A London Blog' (2015) I come across a black and white Imperial War Museum Archive image with the following description:

'A waiter dishes up a plate of American eggs and bacon to a group of people seated at a table outside the empty shell of a severely bomb damaged school. The school has the words 'Sayer Street Schools, 1891' on the stone plaque visible on the right of the photograph. This photograph was probably taken in late August or early September 1941'(Watts 2015).

Moved by the image and its simple description I return to it again and again in my walking. There is in its spatial juxtaposition of ruin and survival an intriguing ellipsis of revelation and concealment reminding me of what Walter Benjamin saw latent in Eugene Atget's turn-of-the-century portraits of deserted Parisian streets. Though the image is populated with human figures, there is too the sense that this is a crime scene, an aftermath on which I can only speculate phenomenologically. Prima facie, it would seem reasonable to conclude that they are three generations of the same family. That the women on the left are perhaps daughter and mother, and the male 
figures, respectively child, father and grandfather. However, what we don't know is whether they all lived together as a household in Sayer Street or, as my later research suggests, in nearby Lion Street with which Sayer shared - fatefully - a communal air raid shelter. They are clearly survivors and witnesses: but of what and to what? How and why were they selected for this late summer morning photo call? Were they looking forward hungrily to the breakfast or, perhaps being chivvied relentlessly through retake after retake, their appetite long since lost? I speculate too, about the setting up of this image - the composition of figures around a table that I connect to a biblical repast, the figures sitting down to what is symbolically a first breakfast, the tableau prefiguring a beginning of an end.

I circle around the table and the tableau. I find a resonance and a possibility for interpretation in Jean-Luc Nancy's writing on form:

Just as the visible form of the table presents us with its use and affordance [disponibilité] as furniture, whether for eating, writing, or climbing up on, the "idea" of the table (tabula rasa, multiplication table, tablature) carries the sense of a general affordance for ... affordance itself, in other words, the form of a surface on which things are arranged, the way forms come to light [mise en evidence] and presence (to sit down at the table, to put something on the table, the negotiating table, the Holy Altar [la Sainte Table]). This form gives sense or truth to the "table.",

(Nancy 2007 [2013]: 6)

There is a certain enigmatic staginess to the picture not helped by a depth of field in which the sharper focus is on the remarkably well-preserved exterior of the school building and where we can make out the plaque more clearly than the individual faces in the foreground. Whether this is a result of the photographer's technical limitations or an editorial decision to reinforce the message that 'London Can Take It', the building intended as metaphor for a nation stoically holding its own against the might of the Luftwaffe, ${ }^{2}$ the effect is to render the human subjects mere cyphers. Unknown but not unknowable, I am determined to pull them into sharper focus.

I scan the image and text Esper-like for further clues. The caption reminds the reader of the significance of provenance and patronage. These are American bacon and eggs and the meal symbolises the new 'Lend Lease' partnership between the USA and Britain. Zooming in to the image it becomes clear that the group's gaze is directed at the white-jacketed waiter's well-practiced ladling of food onto plate. I speculate again, is this stage direction or genuine anticipation? I zoom out. The photograph was taken a few months after the Elephant \& Castle (like other parts of London) experienced the worst night of German bombing on May 10 1941 (Mortimer, 2005: 27) ${ }^{3}$. I knew from my study of the colour-coded London County Council Bomb Damage Maps ${ }^{4}$ that Sayer Street had been heavily bombed and that the injury or death of some of its residents was a very likely consequence. What then had the street looked like in more peaceful times? Where had the school been located? What was the situation of this family group? Had they been made homeless, had they experienced personal loss?

The answer to some of these questions is serendipitously arrived at in June 2017 through an immersion into the local history archives held at the John Harvard Library 
in nearby Borough High Street. I find there the following about the street from J. Hook's invaluable mining of the records's. During the war, Sayer Street School had been the location of the local Women's Institute offering 'a wide choice of cultural, recreative and home-craft subjects'. It had (in its dual capacity as a 'Special School for Children) provided classes for short-sighted children (so called 'myopes') on its top floor and had also served as an ambulance station ${ }^{6}$. The school was clearly an important locus in peacetime and war and this might have been a reason it was selected as backdrop for the image rather than placing the group outside the bombdamaged remnants of their own home.

More ironically plangent, however, is the list of fatalities following a direct hit (presumably) on the communal air raid shelter between Sayer Street and Lion Street:

Frederick Edward Hill (65) of No. 275

Sophia Alice Downing (42) of No. 105

Margaret (53) and Ivy Eileen (26) Lauder of No.261

Sidney James (49) and Annie Gertrude (45) Martin of No.179

Hilda Wild (41) of No.189

I imagine a connection between the two groups. Entertain two possibilities: one, more remote, that they knew of each other through extended networks of kinship or indirect friendship; the other, closer knit - that they were neighbours who socialised together, worked together and in the more distant past had played as children together.

Photographers like Bert Hardy captured the communal life of such neighbourhoods most visible in the shared space of the alleyways between terraces - a place where the quotidian jostle of adults' work and children's play would be interspersed by the key events of the community - births, marriages and deaths. I refocus. Had they huddled together in the shelter during an air raid? Were the family group outside the ruined school still in mourning for the loss of friends and neighbours? I reloop. This family - through the constellation of signifiers denoting class, occupation and attitude - could quite easily have come from the photograph albums of my own family's pre-war history. I see in them something strangely familiar. The photograph strikes me as being close to home.

\section{'Sigiheri'}

Wanting to get more background on the circumstances surrounding the taking of this picture, in early June I email my request to Ian Carter, Senior Curator, Second World War at the Imperial War Museum. He replies that the museum has no information on the identities of the people depicted, nor when or where it was published, only that it was taken by an unknown photographer working for the Ministry of Information as part of a project to document wartime Britain. He is unable to confirm whether it was specifically intended for US publications, although it may well have been published in America. It was more likely intended to draw the British public's attention to the fact that supplies of food from the US - via the new policy of Lend Lease - had started arriving in Britain in the summer of $1941^{8}$. What is certain is that the image was taken after the worst night of raids, $10^{\text {th }}$ May 1941, when Luftwaffe bombers created a ferocious firestorm that rapidly engulfed the Elephant. 
My disappointment at this seeming dead end dissipates however when, shortly after, a friend sends me an online link to the etymology of 'Sayer'. The intriguing panEuropean origins of the name prompts a polysemic way of seeing the image in relation to Lend Lease Ltd.'s re-appropriation of Sayer Street for its Elephant Park development. 'Sayer' is the Middle English for 'to say' and 'assayer' means 'trial' or 'test', from the French 'essay' deriving from the Latin exagminare meaning 'to weigh' and thus an occupational name for an assayer of metals or a taster of food. Both resonate when I contemplate the picture. What is then signified? That the image is speaking or saying something; that the family group of (presumably bombed out) working class Londoners about to enjoy a breakfast of bacon and eggs communicates an iconic stoicism - a mythic quality amplified in the Ministry of Information posters of the period ('Your Courage, Your Cheerfulness, Your Resolution, will Bring Us Victory')' and through the analogue of a key American film adaptation of a 1940 British novel about a wartime family released in $1942^{10}$.

The most reverberative in this relay of signifiers however is the coincidence that one of the oldest roots of Sayer is 'sigiheri' from the Old German for 'victory army'. The photograph yields a twofold sense of this: one, ironic - the swift victory against Britain that the Luftwaffe high command had expected their concerted bombing of civilians would bring them, the other, contingent upon the association with the picture's function as propaganda (British and American) is in the sense that Lend Lease food aid is a precursor to America's full involvement in the war. These senses, together with the grainy inscrutability of the figures (did they experience cheerfulness and resolution in the set up and duration of this photo opportunity I wonder?) seals the overwhelming meaning. I am reminded of 1940s screen depictions of the civilian populace during, and shortly after the war - through, for example, the Mass Observation documentaries of Humphrey Jennings (Fires were Started (1943) and Diary for Timothy (1944) and via the 'realist and fantastical' cinema of Powell and Pressburger - The Life and Death of Colonel Blimp (1943) and A Canterbury Tale (1944)."

Although the Sayer Street tableau predates these representations, I experience it as homologous - perhaps somewhere in the documentation of these filmmakers this image figured as source material. Certainly, there is another echo in the post-war Ealing films that depicted a London emerging from the ashes whether in the mild utopian fantasy Passport to Pimlico or the bombsite playground mise en scène of Hue and Cry.

All these connotative associations further ground an ironic quality to do with the ultimate zero-sum game of this mode of warfare. 


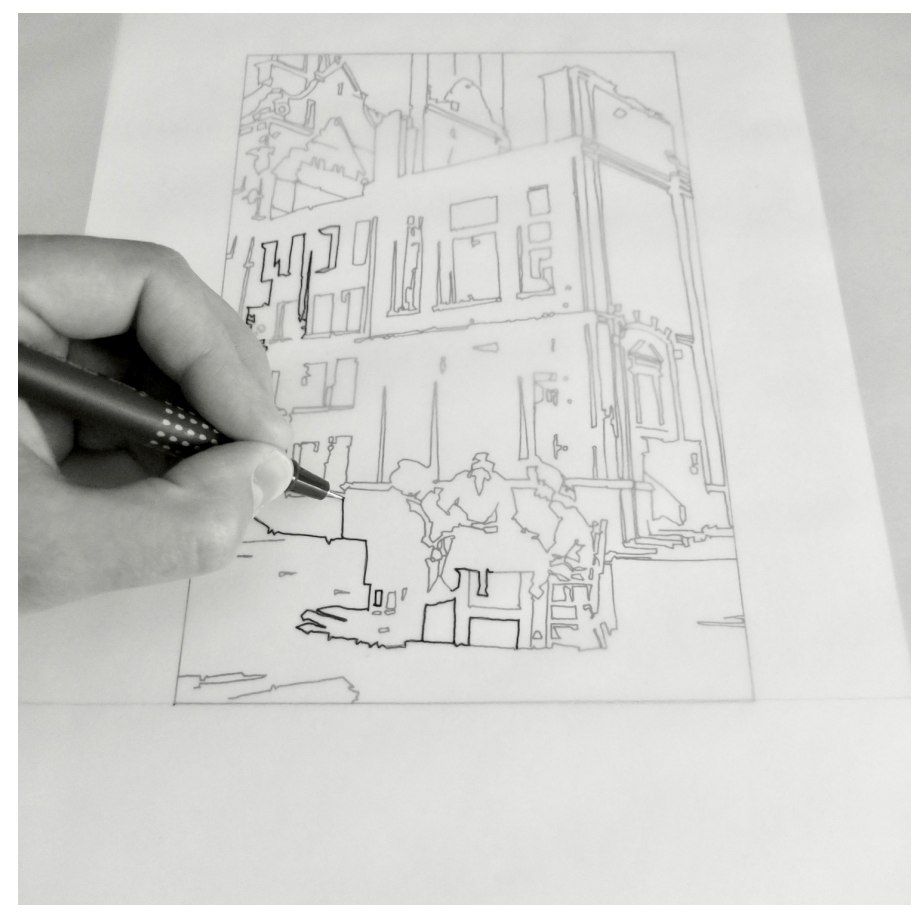

Figure 2. Image: Corinne Noble, Sayer Street tracing, August 2017

\section{Close to Home}

There is then something eerily familiar about the figures around the table, something that triggers in me an involuntary memory of wartime - a memory that is my mother's but one I relive through her many retellings at family gatherings of the night in 1940. She (then 5 years old) woke up to hear lions and tigers roaring down the chimney. It is the night her sister could have been killed and the night her playmate was killed as a result of the direct hit on Vicarage terrace.

I telephone my mother to hear again a story that starts with the chance first meeting of my Scottish grandfather Tom and English grandmother Grace as they promenaded along the seafront in Deal, Kent some 22 years before. While Grace had been holidaying there, Tom was recuperating in a nearby military hospital having been recently invalided from the trenches with shrapnel wounds and suffering the traumatic effects of mustard gas poisoning. It was a long courtship, they married in 1930, but by 1932 they had an infant daughter - my auntie Mary - and were renting a late Victorian terraced house in Edward Street in the 'town' rather than 'gown' part of Cambridge. My mother Joy was born a year later. In 1940, no longer fit for active service, Tom was a volunteer ARP (Air Raid Precautions) warden.

Grace, gentle and devout, played piano each Sunday at the local church and was a dressmaker with a reputation for fine needlework. Tom however, perhaps as a result of his experiences at the front was often dour and irascible (what would now perhaps be ascribed to post-traumatic stress disorder). Employed by the Ministry of Works, he worked as a maintenance engineer on industrial boilers and when America entered the war in 1943 serviced such machinery on nearby USAF bases in East Anglia. My mother has a strong memory of the delicious donuts he often brought back as well as 
another source of food aid in the packages of tinned goods ('Peaches in syrup!') that were regularly sent by a distant relative who lived in Detroit.

What woke my mother from her dream of wild animals that night was the loud crump of bombs and the sound of an air raid siren. She vividly remembers running outside with her parents amid the blind panic of people in the street and can still picture a next-door neighbour known as Auntie Bacon, in her night dress, long grey hair flying and sans dentures, rushing towards the communal air raid shelter.

What was learnt when the all clear was given the next day - my ARP grandfather was one of the first on the scene - was that Vicarage Terrace which ran parallel to Edward Street had taken a direct hit and the houses between 1 to 6 were completely destroyed, leaving their occupants dead or gravely injured. On the even numbered side of Edward Street there was damage too, caused by the flying debris that arced over from the direct hit on Vicarage Terrace. The roof of number 16 directly above the top floor bedroom where my aunt would have been sleeping had been pierced by shards of metal and masonry ('Cambridge brick') that landed on her bed. My mother remembers prayers being said for one of the dead victims - a little boy - her playmate ('Trevor?') who lived in the sweetshop at 1, Vicarage Terrace.

This is the most detailed account my mother has given me. A key detail - Vicarage Terrace - the reason to tap these words along with 'air raid', 'Cambridge' and '1940' into a search engine. What I discover via a local history website and an archived BBC Cambridge report astounds me. This air raid was carried out on the night and early morning of June $18^{\text {th }}$ and $19^{\text {th }}$, only a week or so after the evacuation from Dunkirk and three months before the beginning of the air war on London known as the Blitz. The strategic target was apparently a railway bridge close to where the bombs fell but the people who died in Vicarage Terrace were the first British civilian casualties of the war.

I send my mother the links ${ }^{12}$ which both contain an original two-paragraph report with a photograph of the clear up that was published in the local newspaper. She tells me that she thinks that the figure on the mound in cloth cap and what looks like dark overalls holding a blanket with another man higher up is my grandfather. 


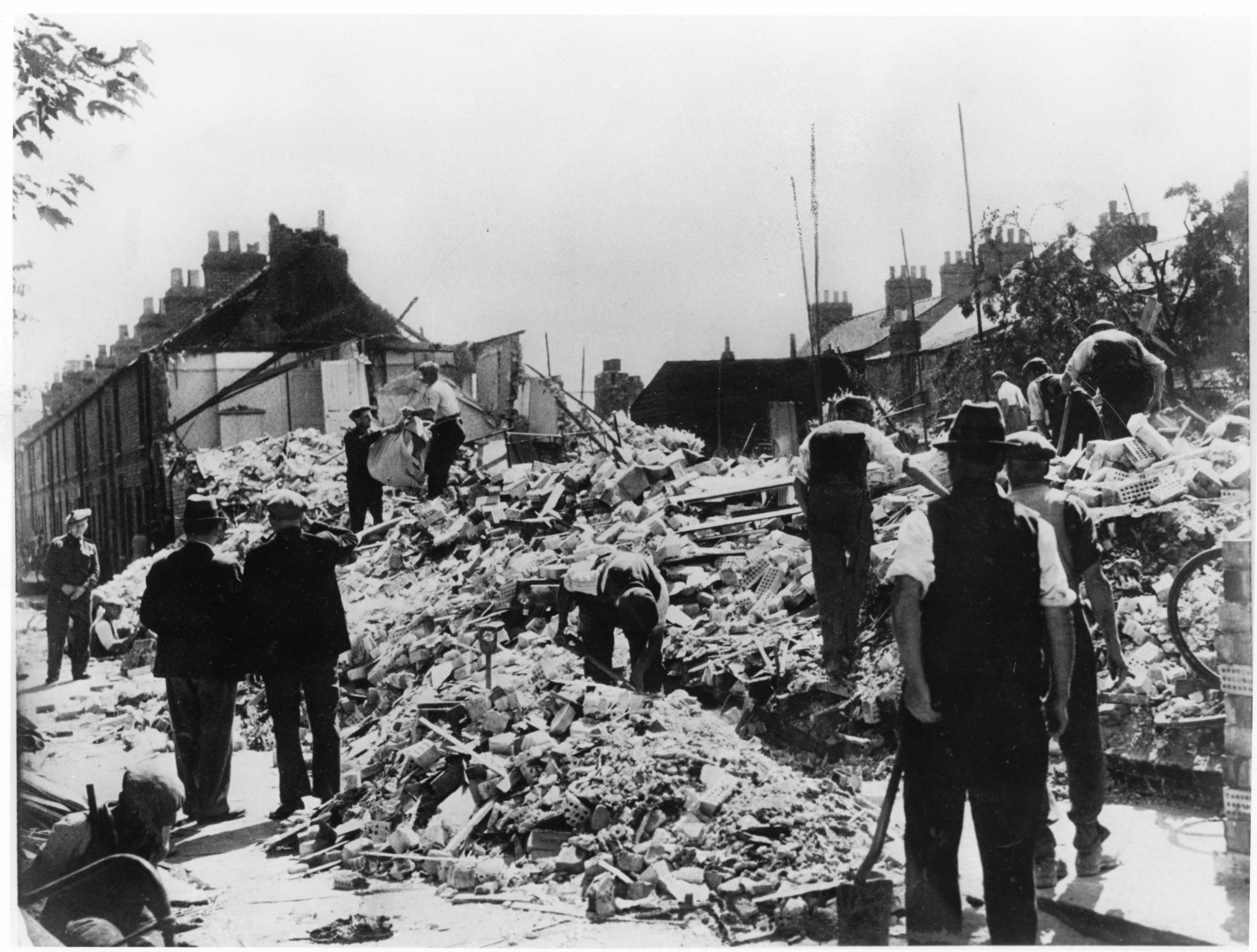

Figure 3. Image: Cambridge Central Archive, Lion Yard, Cambridge

\section{Re Mapping}

1889:

At NW of Lion St are Lion Buildings. 1882. "Belongs to a private lady." Red brick, lately done up outside and do not look worse than LIGHT BLUE but have a very bad reputation, "an awful police". Drunks and fights, shoeblacks and loafers, women flowersellers, a few thieves. Narrow stair entrance.

LIGHT BLUE-barred, in map DARK BLUE-barred... Like them are Weymouth Buildings in Sayer Street. LIGHT BLUE-barred, in map DARK BLUE-barred. The rest of Sayer Street is PINK to PURPLE, more PINK than is on the map.

1941:

Sperrle's finger headed back over Blackfriars Bridge like one of the legions of commuters returning home. Now he was in Southwark, going straight down the Blackfriars Road, over and across St George's Circus, into London Road for a quarter of a mile and there was the Elephant \& Castle. He tapped the map lightly a couple of times. The Elephant \& Castle, what an absurd name. ${ }^{14}$

The route on the Luftwaffe map of London traced so physically and unerringly by Feld Marschall Hugo Sperrle on the eve of May 10 1941, the worst night of the London Blitz, in Gavin Mortimer's evocative imagining, connects these two wartime images in another respect. That is, in capturing something of an aftermath (the first 
remoter than the second), they evince a negative potential, and in these two images the sense of a map definitely being in the wrong hands.

There is a sense too of a map in the wrong hands whenever I use one to navigate the spatial and temporal coordinates of Elephant Memory. However, following a recent diagnosis of dyspraxia I can make sense of my life-long propensity for 'getting lost' including my frequent difficulty in determining north from south, east from west, and the stress I often experience when required to read a map in public situations. More positively, I have long embraced this perceived deficit for its performative and dialogic possibility when walking with others; getting lost, getting lost in maps, getting lost in time.

Three old maps of the area around Sayer Street inform this dis/oriented seeing while walking. One, seen in the image above and found online, is a 1930s era A-Z map likely attributable to Phyllis Pearsall ${ }^{\text {is }}$ that shows Sayer Street running parallel with Lion Street at the beginning of the New Kent Road as it runs southwards from the Elephant \& Castle roundabout. While the bold black lines and place names on white background mostly denote a faithful rendering of the Elephant \& Castle's distinctive arterial layout, the map also conjures a neutral moment between a dark recent past and a dark soon-to-come future, that is, between the extreme poverty of the 1890s and bomb devastation of the 1940 s - respectively symbolised so memorably in the dasymetric colour coding of the Charles Booth and London County Councilcommissioned maps. I see in them a terrible beauty, the palettes of yellow, orange, red, purple and black redolent somehow of bruising, of harm done. They too, look like scenes of crime.

With these fragments, discussion while walking returns to a constant theme - the sense that we are detectives obsessively working to solve a cold case with little to go on but the Imperial War Museum's brief provenance and an indication of the location (the family group are seated outside the ruins of a school). Brian Dillon's observation about ruins serving as remnants and portals into the past seems particularly apt as I search for further clues in the maps and images that we use to navigate our way. 


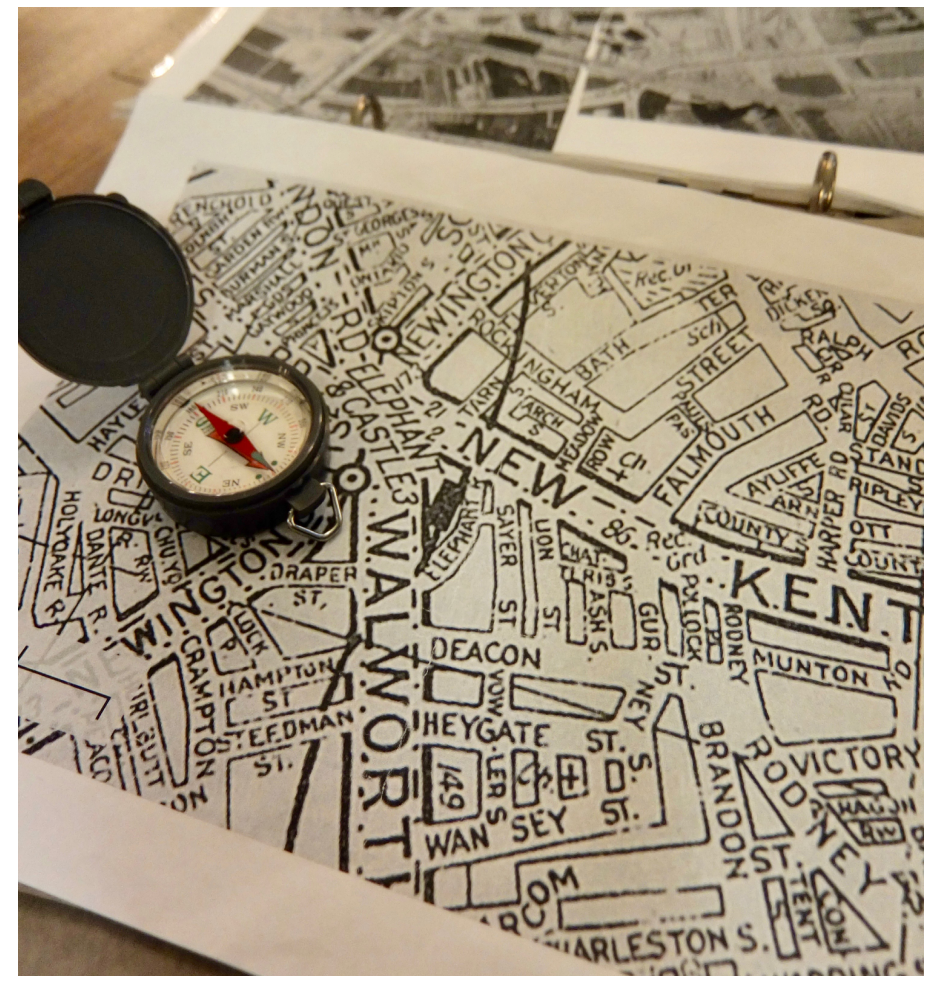

Figure 4. Image: Corinne Noble, July 2017

\section{Placeholding / Placemaking}

2017:

Sayer Street is an historic street name that was used in 1896, up to 1952, running in a North/South orientation similar to that of the proposed new road, almost exactly matching the old street pattern. It is believed that the road was

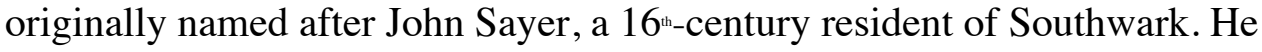
was a Member of Parliament and a Knight of Essex. He was a successful merchant, clothier and innkeeper, which, given his name will be used for the new shopping street running through Elephant Park, is an appropriate link. ${ }^{16}$

It's very interesting (Sayer Street) is coming back. There's something quite unsettling about the way developers fix on these historic incidentals to justify their history-erasing behaviour ${ }^{17}$

As detectives, we are occasionally seduced and side tracked by red herrings and dead ends. For example, we find locations that would have been very familiar to Charlie Chaplin as he was growing up in this part of south east London or to another 'Elephant Boy' - the gangster and adventurer Charlie 'Wag' McDonald ${ }^{18}$ who briefly worked for Chaplin in 1920s Los Angeles. Less romantic but crucial are the political lines of thinking prompted by the social and economic realities of early twenty-first century London living of which the so-called regeneration of the Elephant \& Castle is so representative. Douglas Murphy has provided an excellent account of this in his essay 'London Has to Continually Refresh its Offer'(Murphy, 2017: 42-43) reminders of the winners and losers of the 'Faustian pact' he refers to between 
Southwark Council and Lend Lease Ltd in the grafitto on the bridge leading into the Elephant \& Castle from the Walworth Road:

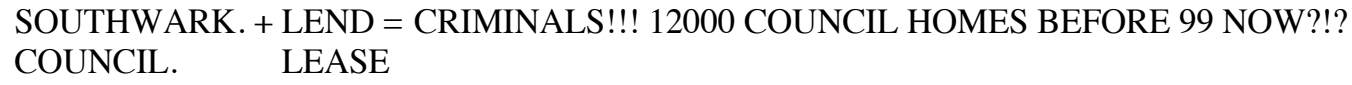

It is the awkwardness of the location of this message that might account for it so far surviving the policy elsewhere of covering over such writing with blocked squares of paint that are oddly suggestive of Josef Albers. I speculate on whose instruction this has been carried out (Southwark Council's? Lend Lease Ltd.'s?), as the blocking only draws attention to the erasure. Certainly, the anger communicated in the combination of minimal text and duplicated exclamation and question marks is at variance with the cheery narrative of regenerated place making found everywhere on the hoardings around Elephant Park. Here the appeal is to a sort of good life - a connection I make to Roland Barthes' elaboration of the semiotics of the savoir vivre in post-war French advertising. I look back at the notes I had written about this line of thinking on my July walk with the artist Corinne Noble:

Walking alongside the perimeter and its advertising we see what looks like a Photoshop image of Sayer Street as it will be - a place of al fresco dining and shopping. We see mostly young, affluent-looking people, a summer's day and placeholder businesses: 'The Roasted Bean Coffee Company', 'The Elephant Deli', 'The Castle Canvas', 'Elephant Fine Wines', and 'Elephant Night Fly' (selling some weird charcuterie it seems). The overall effect is to communicate an idealised depiction of the enjoyment of consumption and leisure.

We read off the hoarding's digitally-rendered image and text against the 1941 photograph and detect in both parallels of placeholding and placemaking. The wartime image certainly yields a metonymic possibility in the placement and location of the family group - a sense through them that a line has been held and a post-war future reconstruction of Britain - through the setting up of the welfare state - foreshadowed. Similarly, the Lend Lease Ltd advertorial points to a near future but one in which reconstruction for the many is replaced by regeneration for those who can afford it. This theme of winners and losers has particular resonance in the wake of the conflagration of Grenfell Tower in west London on 14 June 2017. The subsequent furore around Kensington \& Chelsea's public housing policy and in relation to this, Jeremy Corbyn's condemnatory phrase 'land banking,' seem to be particularly relevant to those who have lost their stake in the Elephant's bright new future.

We consider as we walk in the wake of this event how Lend Lease Ltd seeks legitimacy / respectability for its project through an appeal to history - one in which its recuperation of the name 'Sayer' - is crucial. However, at the time of writing the exact coordinates of the new Sayer Street are yet to be finalised. On the last walk, for example, an inspection of the architects' model map in the showroom at the Elephant \& Castle reveals its placeholding name to be simply 'Central Shopping Street' and the helpful representative we speak to can only confirm that the completed section runs through what the 1930s map reveals to be Vowler Street, while where it will come out onto the New Kent Road will be where Lion Street used to be and what used to be the beginning of Sayer Street is now the location of a new Sainsbury's supermarket. Why then are Lend Lease so wedded to the name of Sayer? 


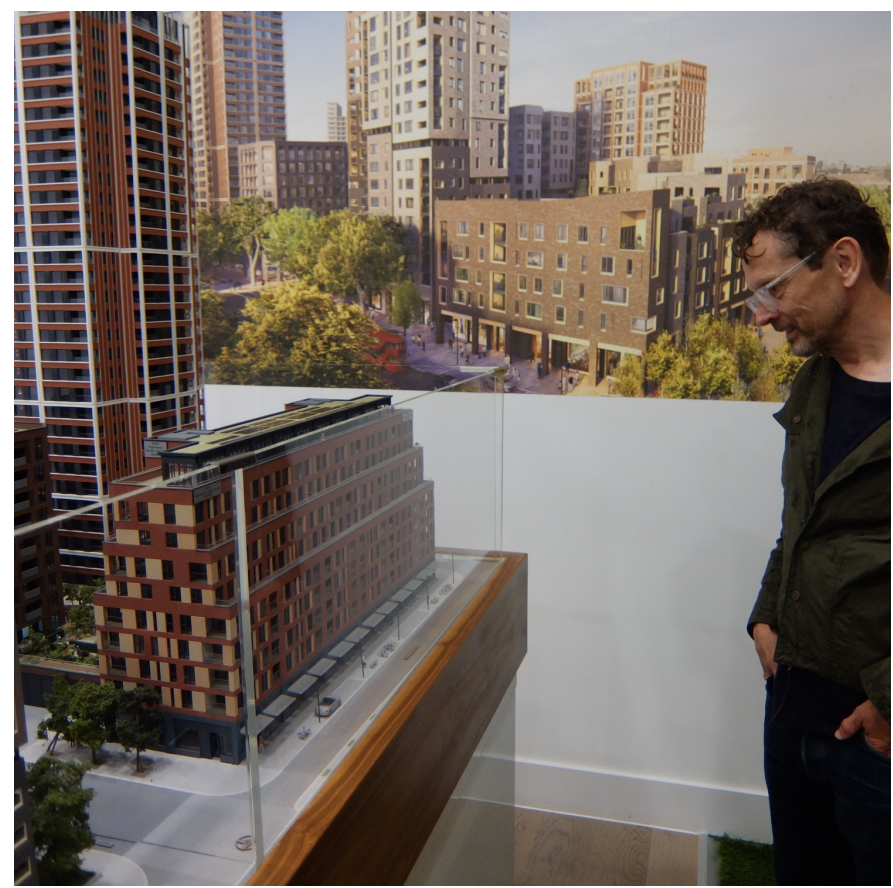

Figure 5. Model of Elephant Park in development. Image: Corinne Noble, July 2017

In late July I email Peter Watts and thank him for the original blog posting that has provided me with so much inspiration. If there has been an element of detection in the research then I must acknowledge him as the original case officer. In our exchange of emails, I refer to some of the anomalies of time and provenance that have arisen. This strikes a chord with Peter:

'I've been thinking a lot recently about the way developers do things like this - there's a new block of luxury housing in Crystal Palace named after Emile Zola, based on the fact he lived there for about 9 months and clearly paying little attention to his socialist sympathies. In Farringdon, they knocked down the Turnmills nightclub and have built a new building where all the conference rooms are named after DJs, and then, when they ran out of DJs, random music festivals, it's cultural appropriation in the name of property marketing and Sayer Street's rebirth is a fine example of this.'

Finally, then, I share Peter's pessimism about such erasures of history through cultural appropriation or recuperation that is a consequence of the marketing and selling of large-scale development projects like this. The history of a place and the people who lived in it is subject to a convenient framing in which deciding the map, drawing the map, holding the map, and through it constructing its narrative is both an act of remembering and forgetting. Another walk is planned for early 2018 when Elephant Park's central shopping street should be finished and open for business. The ghost of the old Sayer Street will have been laid to rest but most definitely not forgotten.

\section{Coda: Reloop}


One further difficulty must also be tackled. If Walworth is decently re-built there will not be room for so many people to the acre, and in consequence there will have to be a considerable exodus. Then will come the question as to which people are to remain, and which to go elsewhere. The only way of answering the question is by a plebiscite. There are some who, despite the grave drawbacks of the neighbourhood would for reasons of business or sentiment, prefer to remain; these are they whose views we are always quote when we wish to excuse ourselves for delays in housing schemes. There are others who remain unwillingly and grudgingly, and who, if they had the opportunity, would be off to some congenial spot to-morrow.$^{20}$

(Browning Hall Adult School 1925: 54)

\section{References}

Ancestry.co.uk 'Sayer Family History' https://www.ancestry.co.uk/nameorigin? surname $=$ sayer [Accessed 2 July 2017]

Barthes, Roland (2000) Camera Lucida, Reflections on Photography (Trans. Richard Howard), London: Vintage Books: 43

Benjamin, Walter $(1979 ; 1997)$ 'A Short History of Photography', One-Way Street, London: Verso: 243

Bond, Fred (1996), 'Obituary: Phyllis Pearsall', The Independent, 30 August 1996, http://www.independent.co.uk/news/obituaries/obituary-phyllis-pearsall1312265.html [Accessed 1 August 2017]

Browning Hall Adult School (1925) (Orford, E. J. (Ed.)) The book of Walworth Being the Report of the Scheme of Study for the Year 1925, London: Browning Hall Adult School: 54

Chamberlain, Fonz (2012) 'World War 2 Air Attacks on Cambridge' http://cambridgehistorian.blogspot.co.uk/search?q=bombing+of+Vicarage+Terrace [Accessed 15 September 2017]

Dillon, Brian (2011), 'Introduction//A Short History of Decay' in Ruins: Documents of Contemporary Art (ed. Brian Dillon), Cambridge: MIT Press: 11

Hook, John (1995) THESE ROUGH NOTES: THE RAIDS ON SOUTHWARK 1940-45 PART THREE, SOUTHWARK A Brief History of the Raids in which Fatal Casualties occurred based on Southwark Local Studies Library Archive

Lendlease (2015) 'Elephant \& Castle Regeneration'

http://www.elephantandcastle-lendlease.com/news/first-new-street-names-first-phaseelephant-park-including-tribute-private-lee-ocallaghan [Accessed 1 September 2017] 
Murphy, Douglas (2017) 'London Has to Continually Refresh Its Offer' in Walking Cities: London, Eds. Joseph-Lester, King, Blier-Carruthers \& Bottazzi, London: Camberwell Press: 42-43

Nancy, Jean-Luc (2013), Trans. Philip Armstrong, The Pleasure in Drawing, New York: Fordham University Press: 6

Watts, Peter Sayer Street in The Great Wen, A London blog, https://greatwen.com/tag/sayer-street/ [Accessed 02 April 2016]

\section{Endnotes}

${ }^{1}$ I choose 'reconnoitring' here in the sense of surveying, tracking down, detecting, knowing again - see Peter Watts correspondence (below)

2 "The Germans," before America entered the war, are said to be greatly puzzled over London's willingness to take continual punishment without so much as a thought to surrender. The British, they think, are licked and if, in the end, they win the war it will be due in no small way to the magnificent way in which the people of London are standing up to the siege." Angus Calder (1969), The People's War: Britain 19391945, London: Pimlico: 231

${ }^{3}$ See Gavin Mortimer (2005), The Longest Night - Voices from the London Blitz, London: Weidenfield \& Nicholson

${ }^{4}$ See Laurence Ward (2015), The London County Council Bomb Damage Maps, 1939 - 1945, London: Thames \& Hudson

5 John Hook (1995), THESE ROUGH NOTES: THE RAIDS ON SOUTHWARK 1940-45 PART THREE, SOUTHWARK, A Brief History of the Raids in which Fatal Casualties occurred based on Southwark Local Studies Library Archive

${ }^{6}$ Ibid. pp. 32-33

${ }^{7}$ Ibid. p.29

8 '...Lend-lease shipments of dried eggs, evaporated milk, bacon, beans, cheese, lard and canned meat, which began in the summer of 1941, were crucial in the battle to maintain the quality of the nation's diet. The first consignment reached Britain on May $31^{\text {st }}$, and Lend-lease contributed one-fifteenth of all food arriving in the country in 1941. Such blessings were so much appreciated that Mass Observation, in August, found that more people wanted America to stay out of the war than wished she would come in; chiefly because it was presumed that there would be less aid for Britain in the latter eventuality.' - Angus Calder (1969), The People's War: Britain 1939-1945, London: Pimlico: 231 
${ }^{9}$ For a discussion of this and the other two posters in the series see Owen Hatherley (2016), The Ministry of Nostalgia, London: Verso: 19

${ }^{10}$ Mrs Miniver - credited by Winston Churchill as playing a key part in consolidating American public support for entering the war as an ally

${ }^{11}$ For an interesting evaluation of their oeuvre, see Adrian Danks, 'The Director as Peeping Tom: A Matter of Life, Death and Cinema' in Great Directors, Issue 20, May 2002. Available online at http://sensesofcinema.com/2002/greatdirectors/powell/

${ }^{12}$ http://news.bbc.co.uk/local/cambridgeshire/low/people and places/history/newsid 8754000/8754009.stm http://cambridgehistorian.blogspot.co.uk/2012/06/bombing-ofvicarage-terrace $7702 . \mathrm{html}$

13 'A street coloured black represented the lowest class, vicious and semi-criminal, that of dark blue the very poor and casual labourers in chronic want and that of light blue the 'poor' with an income of 18 s to $21 \mathrm{~s}$ a week for a moderate family. A purple street was one with a mixed social class - with some comfortable and others poor. A pink street was 'fairly comfortable with good ordinary earnings', a red street middle class and 'well-to-do' while a yellow or gold street housed mainly upper-middle and upper class, wealthy families.' -

https://collections.museumoflondon.org.uk/online/object/541998.html

14 'By 9 a.m. (Sperrle) and Koller had divided the English capital into three generous portions. The East End and the city's financial district, Westminster and north as far as King's Cross Station; and south of the river from Greenwich to Clapham in the west. In the centre of this third target zone lay the Elephant \& Castle.' Gavin Mortimer (200, The Longest Night - Voices from the London Blitz, Weidenfield \& Nicholson, London, 2005 p. 27

${ }^{15}$ http://www.independent.co.uk/news/obituaries/obituary-phyllis-pearsall$\underline{1312265 . h t m l}$

${ }^{16} \mathrm{http}: / / \mathrm{www}$. elephantandcastle-lendlease.com/news/first-new-street-names-firstphase-elephant-park-including-tribute-private-lee-ocallaghan Accessed: 24th June 2017

${ }^{17}$ Email to author from Peter Watts, 26 ${ }^{\text {th }}$ July 2017

${ }^{18}$ See Brian McDonald (2005), Elephant Boys: Tales of the London and Los Angeles Underworld, London: Mainstream Publishing Company Limited

${ }^{19}$ Douglas Murphy (2017) 'London Has to Continually Refresh Its Offer' in Walking Cities: London, Eds. Joseph-Lester, King, Blier-Carruthers \& Bottazzi, London:

Camberwell Press: 42-43 
${ }^{20}$ E J Orford, Ed. (1925) The book of Walworth - Being the Report of the Scheme of Study for the Year 1925 Browning Hall Adult School: 54 